\title{
Using Literature in Bibliotheraphy: Biography Sampling
}

\author{
Müzeyyen Altunbay \\ Correspondence: Müzeyyen Altunbay, Giresun University, Education Faculty, Turkey.
}

Received: September 2, 2018

doi:10.11114/jets.v6i11.3593

\author{
Accepted: September 25, 2018 \\ Online Published: October 9, 2018 \\ URL: https://doi.org/10.11114/jets.v6i11.3593
}

\begin{abstract}
Bibliotherapy is consisted of a combination of the Greek "biblion (book)" and "therapeia (therapy-healing)" which have become popular since the 20th century as one of the alternative therapy methods. It is used to make individuals identify themselves with the works they read through works of high literary and aesthetic value and make them powerful individuals in the spiritual direction by producing solutions to the problems they experience in this way. In other words, bibliotherapy can also be defined as bringing the right books to the individual at the right time. That is, the history of accepting the idea that books are good for man is very old. In this study, the importance of using biographies will be explained in one of the important alternative therapy methods, bibliotherapy. There are some criteria in the selection of books because they are the most important materials that form the basis of bibliotherapy. As it is known, the process is three dimensions as the advisee, book preference and consultant. However, it is not possible to use every work in bibliotherapy. It is important to use the works that are high in reality dimension and keeping a mirror on the problems of the individual in bibliotherapy. This process includes the works that will develop the imaginary world of the individual, as well as the works suitable for real life. As is known, the common point in biographies is not only the success that the person who wrote the biography has achieved, but also this person's struggle for reaching his goal is his patience and perseverance. As a result, in the process of bibliotherapy, reading the biographies that will increase the morale and motivation of the individual and develop self-confidence will contribute positively to the person. Moreover, the preference of the biographies of the positive role-model in the society will be the example for the individual.
\end{abstract}

Keywords: bibliotherapy, biography, literature, literary genre

\section{Introduction}

Each era has different expectations from the people as well as the responsibilities it imposes on them. Increasing urbanization after the industrial revolution has brought new responsibilities to human beings. 20th and 21st centuries have the highest expectation from humanitarian. It is expected that there should be various competencies in an individual in the present age.

For instance, these competencies include having a full knowledge of technology, knowing a few foreign languages, communicating, being an entrepreneur, learning to learn, being open to development, following the world, etc. It is inevitable that the person who incur so much responsibility reaches a stalemate from time to time because of fear of failing to meet expectations. The high level of human expectation in the 21 st century also directly affects the psychology of human of this century. That's why; people are increasingly in need of support and help from others. In this century, where psychological problems such as anxiety, stress, low motivation, etc. are on the highest level, the search for a solution to these problems that reduce the quality of life of the individual leads to finding new treatment methods.

Despite the developments in psychology in the 21st century, it can be said that individual searches have increased significantly. Bibliotherapy, which emerges as a result of people searching for their own solutions to their own problems, aims to find solutions to psychological problems through the use of literature. Hence, literary works, which can also be used to increase morale and motivation, take an important place in bibliotherapy.

As it is known, literature has a structure that is good for the human spirit and influences it. Literary artifacts are created from the events that have been experienced or are possible to live. Feelings such as love, hatred, compassion, etc. are real even in fairy tales with extraordinary possibilities. For this reason, the works that describe the human being open a new door into different worlds of the individual and affect the depths of his soul. Considering this fact, it can be said that it goes back very early in the history that people have been interested int books, solve their problems through them and try to treat the soul by using them. For this reason, the exact explanation of what bibliotherapy is and knowing its 
history will also be the answer to the question of why we should use books more.

In this study, it will be attempted to explain the use of biographies in bibliotherapy, one of the important alternative therapy methods of the 21 st century. Thus, the study will first mention the bibliotherapy and history, and then the reasons for using the biography in bibliotherapy will be presented.

\section{What's Bibliotherapy?}

Bibliotherapy is formed by a combination of the Greek biblion (book) and therapeia (therapy-healing) words which have become popular since the 20th century. It is used for the individuals who have emotional problems and tries to make them identify themselves with the works they read through literary and aesthetic high art works and also make them powerful individuals in the spiritual direction by producing solutions to the problems (Altunbay, 2018).

Bibliotherapy, first described by Samuel Mchord Crothers in 1916, aims to produce solutions by using literature in the treatment of individuals suffering from mental problems. Bibliotherapy, which is increasingly prevalent especially after World War I, is now widely used. As it is known, World War I caused millions of people to be killed and disabled, and millions of people had to struggle with economic, social and political depression following the war. In the treatment of the trauma and collapse that this environment created in the human spirit, alternative methods and new applications were used to utilize. One of these is bibliotherapy.

Bibliotherapy, which is one of the alternative therapy methods, improves one's self-confidence and enables him to be able to solve his own problems so that the level of awareness gets higher. Whilebibliotherapy was introduced by Crothers in the 20th century and its history is very old, McCullis (2012) indicates that a manuscript was written "Healing place for the soul" in Alexandria Library in Egypt during BC in the 300s. However, it is known that literary works are used for bibliotherapy as well as religious books. Yllmaz (2014) states that the Qur'an was used for medical purposes in Al-Mansur Hospital in Cairo in 1272. In the following centuries, there are examples of the use of books for therapeutic purposes. McCullis (2012) stated that Benjamin Rush, who is the forerunner of the American psychiatrist at the beginning of the 19th century, aimed to establish libraries as part of the hospital for both education and enjoyment of patients in hospitals at a conference held in 1802. In the following years, it is seen that this idea influenced researchers too. In the 1920s, it is known that S. Peterson Delaney used books in his treatment of psychological and physical discomforts of veterans in the Alabama State Military Hospital. Delaney interpreted this process as treating a patient using selected reading sources (Bulut, 2010).

Bibliotherapy is currently used in education as well as psychology. It seems to be used for purposes such as making the student realize that others have similar problems through the works recommended in education, providing alternative solutions for problems, contributing positive self-awareness development, decreasing emotional and mental stress, increasing motivation.

The use of bibliotherapy in the class also gives the teacher the opportunity to recognize and understand the student. For example, one can get an idea about his or her relations, likes, worldview by looking at the interpretations and perspectives that the individual has made about a work, event, character etc. This also helps the individual organize appropriate educational and training settings or orient them appropriately to their interests.

Increasing prevalence of bibliotherapy also includes questions about whether it is beneficial or not. Some researchers working in this direction have found that the use of bibliotherapy has the following benefits (Cornet\&Cornet 1980; Frasier\& McCannon,1981; Riodan\& Wilson 1989; Pardeck, 1991; Landreville \& Bissonnette, 1997; Frieswijk vd. 2006; Becker vd. 2008; Cross\&Cross, 2009; McCulliss\& Chamberlain, 2013): Positive development in individuals' attitude, positive effects in solving problems, reducing stress and anxiety of children and adults by improving problem-solving skills, improving critical thinking skills, self-evaluation capacity and gaining insight into people's behavior, acquiring high-level reasoning skills, and producing alternatives to problem solving.

The increase in bibliotherapy-focused academic works in recent years is also important because it shows that this area will be one of the most popular areas in future. The book titled "Treating Child and Adolescent Aggression Through Bibliotheraphy" by Zipora Shechtman who is the Professor of Library Science (2009), "Bibliotherapy" by Tews (1962), and "Bibliotherapy: True Book At the Right Time" by Coronette (1980) are some of these works about this subject. There are also a number of scientific papers published theoretically and practically in relation to bibliotherapy.

Bibliotherapy is now divided into sub-areas. While Rubin (1979) distinguishes bibliotherapy as traditional, clinical and developmental; Braynt and Roberts (1992) divide it into advisee-focused and advisor-focused (Ilter, 2015). This classification, which is seen in bibliotherapy, may vary according to the purpose of utilization, material, target group, and practitioner's characteristics.

A model proposal for the use of bibliotherapy in classes that have gifted and talented students was developed by Leana Taşçılar in 2012. The developmental bibliotherapy used here emphasizes that good individual skills can be directed 
better and teachers should be conscious about the subject in this process.

Bibliotherapy, consists of sections such as identification, catharsis, and insight. These steps can be explained as the following:

a. Identification (Level 1): The identification of person's emotional integration with another by putting himself / herself in the other's stead is the first step of bibliotherapy and refers to the integration / identification of the advisee with the hero of the work (Altunbay, 2018).

b. Catharsis (Level 2): Aristoteles, explains the concept of catharsis as a cleansing of the soul's passions in his Poetika. "At this level, the person observes the process of the hero's difficulty, or the problem which he or she is facing, and pay attention to how the event is accomplished. While children share their feelings at this level, the reaction of adults can be weeping or laughing" (Leana Taşcılar, 2012: 122).

c. Insight (Level 3): Through reading, the individual feels that the problem he or she is experiencing does not belong solely to him, there are also people with the same pain or similar problems. So, he purifies from the thoughts that make him feel alone such as "Does this only happen to me?" or "Why am I just getting through this problem?"

The use of bibliotherapy in education for psychological support purposes - although not consciously - has been practiced for many years in fact. For instance, books recommended to the students, the source materials used in the class and the texts in the textbooks should be chosen carefully because they are in a structure that can directly affect the spirit of the individual. For this reason, the criteria that should be selected in bibliotherapy, the qualifications of these works and the relation of bibliotherapy and literature should also be considered.

\section{Relation of Bibliotherapy and Literature and the Use of Biography}

Books are the most important material that forms the basis of bibliotherapy. However, it is not possible to use every works in bibliotherapy. There are some principles in the selection of works. The first point to be considered is the individual and size of the problem he gets through. Since bibliotherapy will be insufficient to solve advanced psychological problems, different treatment methods may be needed. In particular, books can be significant helper about the problems which can be sighted in adolescents and early adolescents with low self-esteem, exam stress, lack of motivation. Above all, defining the problem, choosing the right book and planning the process form the basis of a successful bibliotherapy process. Otherwise, if the process is not well planned, the individual will not be able to contribute, and the existing problems will not be resolved. For this reason, Holmes (2006) points out that the works to be used in the bibliotherapy process should be carefully selected according to the language, linguistic knowledge, concepts, story, and the message.

Literature and bibliotherapy, which aims to cure/improve through literature, are two related fields. As it is known, every work comes out of a long literature process, and the narrative texts (novel, story, etc.) especially in bibliotherapy consist of a large number of factors such as the hero, the language and the style, the subject and the message. In this respect, it is not right to choose a random work in the process and it is necessary for the consultants to have a good literary accumulation, in this regard (Altunbay, 2018).

It can not be claimed that every work read and preferred by the individual is read for bibliotherapy purposes. However, it can be seen that some works are read again because they are good to the person. For example, it is known that some works affect readers, increase their knowledge, and change their feelings and thoughts. However, it should be accepted that it is not possible for each work to produce definite and invariant solutions for each problem. Similarly, the work utilized for the solution of the problem at a certain time should be accepted as not to be effective in the similar process in later processes. Even if the problems are the same, many factors such as the age, experience, anticipation, interest of the person may change.

For instance, the serial work of İpek Ongun, Bir Genç Kızın Gizli Defteri (A Secret Book by a Young Girl), Gülten Dayioglu's Yeşil Kiraz (Green Cherry), Ferenc Molnar's Pal Street Children, Vasconcelos' My Sweet Orange Tree, Edmondo de Amics' Heart are some of them. In fact, it can be said that these works are among the most popular books of youth and adolescence in general. The subjects studied in the books, language and stylistic features and their ability to address the spirit of the individual, including their problems contribute to the books' being read with enjoyment.

Although these and similar works are not intended for direct bibliotherapy, they are read with interest among young people because they are good for them, reflect common problems and relieve them psychologically. The books to be used in bibliotherapy should have some features for this reason. For-example, they should have similar problems that individuals have, help to solve problems, be emotionally relaxed, have indirect experience, be able to identify with the reader's own past, create realistic solutions to the problems in the book, and should present the characters. The books should not be long and complicated. 
It is important that the works to be used in bibliotherapy should be authentic. The more important the works that will develop the imaginary world of person, the more suitable the works for real life are in this process. Works that always end with a happy ending such as fairy tales should not be given. Since he identifies himself with the idea, too emotional works should not be preferred. The preferred work should encourage the individual, increase self-esteem and inoculate emotion of success or overcome the problems by enhancing the motivation.

It is important that the heroes in the literary works have common features with the reader, because "whatever age group the child is, he identifies himself with the heroes of the books he reads. The writer has to know this and constantly consider the direction of this identification when he chooses his heroes." (Yalcin and Aytas, 2008: 47). In this context, the choice of works with high share of reality will contribute to making the process more meaningful. When the individual knows that what is happening in the work he is reading is real, he will find a solution to his problems and the power to deal with his problems.

Throughout life, -especially during adolescence- it is possible for an individual to find many real or fictional models with which they can identify themselves such as cartoon characters (Batman, Iron Man, etc.), comic books characters (Pokemon, Lucky Luke, etc.), a famous name or a novel's hero. However, it should not be overlooked that the works have high share reality will have more power to influence. For this reason, biographies are one of the most effective literary genres that can be used in the bibliotherapy process.

\subsection{Biography}

As a literary genre, biography is known particulary in literature and other areas such as works of art, politics, science, trade, as well as works describing the lives of well-known people and their work. Biographies have two important characteristics. The first one is completely real, and the second one is an unbiased view. The person described in the biographies takes part in the work with all its features. Childhood, youth, education and business life, private life, difficulties, successes, personality, habits and character etc. All these factors are presented in detail.

An important distinction between biographies and other genres is the requirement that the things told should be documented. The justification is required to prove what is explained in the biography. Biographies may also show some differences according to the writing technique. However, it is an important work that can be used in bibliotherapy in terms of creating role model, positive self-awareness development and high value of reality.

Aytas (2013) stated that people who succeeded and achieved a province for their country are positive examples for children, motivating them to collect and read effectively. It also means that biographical works help to feed the sense of identification.

In this respect, using biographies by making the right choices in the bibliotherapy process will make an important contribution to the individual. Generally, when looking at the biographers, it is seen that their common characteristics are the great and unusual success signers. Many people such as soccer player, political leader, artist, literary man, business man, etc. have biographies. The most important fact underlying the extraordinary achievements of these people is that they must struggle with determination and never give up in a difficult life. Biographies in this sense are the books of the life of the protagonists in a community. The use of biographies of people who have made important studies in the bibliotherapy process will have a positive effect on the individuals who have psychological problems. According to Uslu Ustten (2014), it is more enjoyable and fun to read biographies based on the facts but have the author's commentary for young people. For instance, Steve Jobs's biography has been written based on the facts but the writer also includes his comments about the events and Job's feelings.

\subsection{Sample Works That Can Be Used}

There are many important names' biographies written in world literature. However, among them, it is necessary that the people's biographies must be read and taught who especially survived a difficult life, had their signature in important achievements, and whose work and determination are exemplary to ones coming after them. The biography of Marie Curie, whose work on radioactivity has won the Nobel Prize in two different areas, is one that should be taught as an example. The biographies of Sigmund Freud, who revolutionized psychology in the 20th century and Frida Kahlo, which is a tumultuous life between true love and art love, are also works to be taught. The biography of Elon Musk, a young entrepreneur, tells the process of transforming the wide-ranging imagination of the world into reality, or the biography of $\mathrm{N}$. Tesla, one of the greatest inventors of the twentieth century, provides new point of views to young people.

In addition to biographies, autobiographical writings that tell about one's own life are also works that can be used in the bibliotherapy process. What is important in books is that reflecting real life, encouragement of the individual and increase in self-confidence. 


\section{Result and Discussion}

Literature, born of the expression of feelings and thoughts that will awaken pleasure and aesthetic pleasure in person is an important field that affects the human soul. Literary genres such as poetry, story, and novel add richness to human beings, leading to different worlds. For this reason, literature is an art form that is strong enough to create behavioral change in the individual.

After 20th century, many factors have negatively affected the psychology of individuals and societies such as changing living conditions and the responsibility of industrial and technological developments to humanity, two great world wars in the 20th century, economic and social crisis, and immigration. The bibliotherapy that emerges as a result of the search for alternative solutions aims at bringing the individual to the right book at the right time. In this respect, bibliotherapy was emerged as a result of searching for a solution to human problems and aims to utilize literary works and thus to use literature in the solution of psychological problems.

Although it was first described by Samuel Mchord Crothers in 1916, the history of using the books for therapeutic purposes is very old. Today, there are three important factors in bibliotherapy which is used by nurses, librarians and teachers besides psychologists: advisee, work and consultant. Above all, the first stage of bibliotherapy is reserved for accepting the individual's problems. The second stage is to bring the individual to the appropriate book. The role of the consultant here is very important; because the advisor's knowledge of literature must be very adequate. That's why, a random book will not help the problem, it may even put the individual in a more difficult situation.

Like every science, bibliotherapy has its own principles and it is differentiated by different scientists. Increasing work on bibliotherapy in the 21 st century is important because it shows an increased interest in this area. So, this puts too much responsibility on teachers and other people such as writers, librarians and psychologists because there is a close connection between literature that affects people and bibliotherapy which aims treatment of people. The works to be presented must reflect real life, be able to address the individual, reflect on his/her problems and have reasonable solutions. For this reason, biographies are important works to be used in the bibliotherapy process. The preference of biographies of people who have a positive role model in society will be an example of an individual. As it is known, the common point in biographies is not only the successful person and also not just the struggle of the person, his patience and determination. For this reason, in the bibliotherapy process, reading of the biographies that will increase the morale and motivation of the individual, develop self-confidence will make a positive contribution to the person.

\section{References}

Altunbay, M. (2018). Common Point of Literary and Psychology: Bibliotherapy. Prof. Dr. Alemdar Yalcin Armagani. Ankara: Akcag.

Aytaş, G. (2013). Literature Knowledge and Theories. Ankara: Illdem.

Becker, K. M., Pehrsson, Dale-Elizabeth, \& McMillen, P. S. (2008). Bibliolinking: An adaptation of bibliotherapy for university students in transition, Journal of Poetry Therapy, 21(4), 231-235. https://doi.org/10.1080/08893670802529258

Bryant, J., \& Roberts, S. (1992). Bibliotherapy: An adjunct to audiologic counseling. JARA XXV, 51-67.

Bulut, S. (2010). Using bibliotheraphy in adult counseling. Turkish Psychological Counseling and Guidance Magazine. 4(33), 46-56.

Cornett, C. E., \& Cornett, C. F. (1980). Bibliotherapy: The Right Book at the Right Time. Phi Delta Kappa Fdueacional Foundation Bloomington. Indiana.

Cross, G. B., \& Cross, L. B. (2009). Bibliotherapy for young children. Journal of Clinical Child Psychology, 5(2), 35-70. https://doi.org/10.1080/15374417609532709

Frasier, M. M., \& McCannon, C. (1981). Using Bibliotherapy with Gifted Children. Gifted Child Quarterly, 25, 81-85. https://doi.org/10.1177/001698628102500207

Frieswijk, N., Steverink, N., Buunk, B. P., \& Slaets, J. P. J. (2006). The Effectiveness of a Bibliotherapy in Increasing The Self-Management Ability of Slightly to Moderately Frail Older People. Patient Education and Counseling, 61, 219-227. https://doi.org/10.1016/j.pec.2005.03.011

Holmes, M. M. (2006). Writing bibliotherapy books for young Children. Journal of Poetry Therapy, 17(1), 39-44. https://doi.org/10.1080/08893670410001698532

Ilter, B. (2015). The Effect of Bibliotherapy Technique on the Perfectionism Levels of Gifted Children. Unpublished Master Thesis. Fatih Sultan Mehmet Foundation University. İstanbul.

Landreville, P., \& Bissonnette, L. (1997). Effects of Cognitive Bibliotherapy for Depressed Older Adults with a 
Disability. Clinical Gerontologist, 17(4), 35-55. https://doi.org/10.1300/J018v17n04_05

Leana-Taşcilar, M. Z. (2017). Effects of Bibliotherapy Program on SelfEsteem Levels of Gifted Students. Balikesir University Journal of Social Sciences Institute. 20(37), 73-95.

McCullis, D. (2012). Bibliotherapy: Historical and research Perspectives. Journal of Poetry Therapy, 25(1), 23-38. https://doi.org/10.1080/08893675.2012.654944

McCulliss, D., \& Chamberlain, D. (2013). Bibliotherapy for youth and adolescents-School-based application and research. Journal of Poetry Therapy, 26(1), 13-40. https://doi.org/10.1080/08893675.2013.764052

Pardeck, J. T. (2008). Bibliotherapy and Clinical Social Work. Journal of Independent Social Work, 5(2), 53-63. https://doi.org/10.1300/J283v05n02_06

Riordan, R. J., \& Wilson, L. S. (1989). Bibliotherapy does it work. Journal of counseling and Development, 67(9), 506-508. https://doi.org/10.1002/j.1556-6676.1989.tb02131.x

Rubin, R. J. (1979). Use of bibliotherapy in response to the 1970's. Library Trends, 28(2), 239-252.

Shechtman, Z. (2009). Treating Child and Adolescent Aggression Through Bibliotheraph. The Springer Series on Human Exceptionality Springer ScienceşBusiness Media, LLC. https://doi.org/10.1007/978-0-387-09745-9

Tews, R. M. (1962). Bibliotherapy. Library Trends, 11(2). 94-216.

Uslu, U. A. (2014). Ilk Genclik Edebiyatı (First Youth Literature). Ankara: İldem.

Yalcin, A., \& Aytas, G. (2008). Children's Literature. Ankara: Akcag.

Yılmaz, M. (2014). Healing With Knowledge: Bibliotherapy. Turkish Librarianship 28(2), 169-181.

\section{Copyrights}

Copyright for this article is retained by the author(s), with first publication rights granted to the journal.

This is an open-access article distributed under the terms and conditions of the Creative Commons Attribution license which permits unrestricted use, distribution, and reproduction in any medium, provided the original work is properly cited. 